\title{
Taxis, Traffic, and Thoroughfares: The Politics of Transportation Infrastructure in China's Rapid Urbanization in the Reform Era
}

Jun Zhang

The University of Hong Kong

\begin{abstract}
Cities have expanded both territorially and demographically at an unprecedented speed during the recent intense process of urbanization in China. This article investigates the material, discursive, and social dimensions of an infrastructural process that has been interwoven with the discourse and practice of urban development in the city of Guangzhou since the 1990s. It takes a 2007 public hearing concerning the short supply of taxis on workdays as an entry point into the politics of urban infrastructure, threading together long-term changes in urban forms, the ritual dimensions of the public hearing, and taxi drivers' downward mobility. The issue at the heart of this public hearing is a pattern of traffic flow caused by intense urbanization in the late Reform period that has led to important structural tensions in everyday life. Yet, under the official ideology of urban development, these structural tensions are de-humanized and rendered a mere technical issue of supply and shortage. In present-day China, infrastructural projects are regarded as technological solutions to a wide range of social and political issues in the process of urbanization; yet their result as part of a material regime is often instead to make these issues invisible.
\end{abstract}

(infrastructure, urbanization, taxi, class, mobility, China) 
On July 24, 2007, a police officer suddenly showed up in front of my building and served me a notice, informing me that I had been chosen to be a representative for a public hearing on raising the quota of taxis in the city of Guangzhou in Southern China. It took me a while to recall that a week before I had signed up to sit in on, not to be a so-called representative to speak in, the July 27, 2007 public hearing held by the government agency Guangzhou Transportation Commission (GTC) on behalf of the municipal government. Allegedly, the public hearing (referred to as the "taxi hearing") was being staged to discuss whether the municipal government should issue 700 new taxi licenses to address the apparent difficulty of getting a taxi during the day in the city (referred to as the "taxi problem"). This hearing was announced in all the local newspapers, along with a simple description of its objectives, the number of existing taxis, the proposed number of new licenses, and their duration.

With the official notice in hand and three days away from the hearing, I felt bewildered: whom was I supposed to represent? Nonetheless, I decided to collect as much information as I could about the desire to have more taxis. Luckily I had been conducting long-term fieldwork on automobility and the emergent middle-class lifestyle in Guangzhou. I immediately contacted my middle-class interlocutors - mostly lawyers, engineers, planners, and other professionals in their thirties or forties - and asked them for their opinions. ${ }^{1}$ I also took a taxi whenever I had to go somewhere in these three days and solicited opinions from the drivers. I gathered roughly thirty replies. Both taxi drivers and the middle-class professionals had similar answers: first, that the hearing was a formality and the government had already made its decision, regardless of what ordinary citizens might say; and second, that the extra 700 taxis would do little to relieve the taxi problem. The only difference was that while the taxi drivers resented the proposal, my middle-class interlocutors urged me to endorse the proposal in the hearing, because "it's better than nothing." Some of them told me that I should propose an even bigger increase.

As my interviewees anticipated, the municipal government declared right after the hearing that its proposal had the representatives' support and 700 taxi license plates would be issued. It staged three more hearings on the same issue in 2008 (for another 1,100 taxi licenses), 2010 (700) and 2012 (1,000). It also held hearings on taxi fare in 2011 and on forhire vehicles in 2014. Not surprisingly, all government proposals faced no serious challenges and took effect soon after the hearings. 
In a country with an authoritarian regime, are these public hearings really nothing more than political shows? Drawing on archival research and a decade of observation, interviews, and casual conversations with middle-class residents, planning professionals, and taxi drivers between 2006 and 2015, this article suggests that the significance of these hearings does not lie in their capacity to expose the hypocrisy of the political regime. Instead, these hearings are ritualistic moments in the politics of infrastructure, moments in which the ideology of urbanization and development is reproduced.

In the past two decades urbanization has swept through many parts of the world particularly in the so-called Global South. It is often uncritically promoted by organizations including the United Nations, which use parameters such as the size of the urban area and the ratio between urban and rural populations to measure the level of urbanization. The level of urbanization is considered an indicator of the degree of economic development in individual countries. ${ }^{2}$ Many countries have adopted this mode of development (Roy and Ong 2011), and China has a particularly intense version of it (Hsing 2010). According to the World Bank, China's urban population increased from $20 \%$ in 1981 to $54 \%$ in $2014 .{ }^{3}$ The process of urbanization has been made particularly visible by the extensive road networks, high-speed railway systems, airports, high-rises, and state-of-the-art buildings - the infrastructural projects (see Campanella 2008; Ren 2011). Funding for these projects came from national and local governments, corporations, and international organizations. Infrastructures have become strategic facilitators of urbanization. Narratives concerning infrastructural matters, such as roads, are stories of progress (for example, Joniak-Lüthi 2016). ${ }^{4}$

Scholars have examined the intertwining relationship between the city and the networked, infrastructural system. Graham and Marvin's (2001) analysis of "splintering urbanism," and subsequent works inspired by their writing, 5 illustrate how practices of urban governance, political economy, and power structures have configured the designs of, and hierarchical access to, infrastructural networks, which have in turn shaped variegated urban lived experiences. Furthermore, as Kaika and Swyngedouw (2000) point out, the fetishization of infrastructural networks—-such as water supply and sewage systems-rose together with commodification of water, both of which were tied up with urban modernity and the ideology of progress in Western European cities. Although their research focuses on Western cities (Furlong 2014), their insights remain highly relevant to problematizing 
"urban growth" in the Chinese context. However, this scholarship tends to depict infrastructures as static objects and material products of external technological, economic, and political decisions. A growing body of ethnographic literature takes a more nuanced and dynamic approach to the workings of infrastructures. It attends to both human and nonhuman actors and examines infrastructures' enactment effects: infrastructures do not simply reflect existing social relationships, but also constrain and enable human actions and technological decisions (Anand 2011, 2012). They are material and symbolic structures that shape imaginations of modernity and practices of everyday sociality (Humphrey 2005; Coleman 2014), and produce forms of violence that often escape the judicial system (Ferguson 2012).

I draw on the strengths of both bodies of literature, and add that the unraveling of the politics of infrastructure requires us to see infrastructures as processes-of building, breaking down, rebuilding, modification, and demolition - that continue to morph over time. Taking a 2007 public hearing concerning the short supply of taxis on workdays as an entry point into this politics of urban infrastructure, I investigate the material, discursive, and social dimensions of an infrastructural process that has been interwoven with the discourse and practice of urban development in Guangzhou since the 1990s.

Guangzhou, or Canton in historical documents, had been a major trading port in the South China Sea region for hundreds of years (Blussé 2008; van Dyke 2005). In the postMao era (the late 1970s to now), due to its adjacency to Hong Kong and its diasporic network, Guangzhou was one of the first batches of cities that opened to foreign capital looking for cheap labor and land. Over the years, Guangzhou has become one of the most economically developed cities in China, and one of the hubs - together with Beijing, Shanghai, and Shenzhen - that have attracted millions of people from all over the country looking for better work opportunities and life. Its territorial size and population grew almost threefold after 1979, holding more than ten million regular urban residents in the twenty-first century.

Guangzhou's municipal government has invested heavily in infrastructural construction. Among many achievements, the city had its first subway line of 17 kilometers in 1997, and by 2013 its subway network consisted of nine operating lines with a total length of 260 kilometers. Roads in the urban areas have expanded from 1,467 square kilometers in 1994 to 10,414 in $2014 .{ }^{6}$ Nonetheless, despite the rapid development of 
transportation infrastructure, Guangzhou residents have accepted it as an everyday fact that it is difficult to find a taxi during the day. Several years ago, many people I talked to thought the cause was, simply, a lack of taxis. In the past three or four years, however, more and more people have started to attribute the problem to traffic congestion, which is becoming increasingly common. Popular opinions tended to blame the increase of private car consumption. Indeed, car ownership has increased from 2.3 per hundred urban households in 2003 to 32 in 2014 . However, my research suggests that the focus on private car consumption masks deeper issues in the reconfiguration and workings of the transportation infrastructure in the process of Guangzhou's rapid urbanization.

In the rest of the article, I first trace the metamorphosis of urban forms from the Maoist and early Reform period (1960s to early 1990s) to the late Reform period (1990s to now), showing how an old urban built environment, political aesthetic preferences, and other political and economic concerns in the infrastructural process have reshaped the urban landscape and led to the everyday traffic pattern underlying the lack of available taxis during work time.

In the second part of the article, I consider the taxi hearing I participated in 2007, focusing on how the taxi issue was problematized and discussed. I focus on taxis and taxi drivers not because I prioritize the taxi network over the bus or subway network, but rather my accidental access to the taxi hearing provided a rare opportunity to observe and experience the encounter of variegated actors with diverse vested interests. The analysis of the taxi hearing demonstrates how the taxi issue was narrowly framed as a calculable supply-and-demand problem without questioning the logic of growth. It is at the public hearing that the political-economic regulatory apparatus becomes apparent. As studies on secular rituals suggest, the hearing served to perpetuate the hegemonic way of perceiving and understanding infrastructural development and urban growth.

The third part zooms in on the changing fortunes of taxi drivers. Despite an everexpanding road network and rising consumption capacity, the institutional and economic practices in the name of improving public transportation have structured the decline of taxi drivers' socioeconomic status. The trajectory of a taxi driver's fortune, in fact, is that of downward social mobility in the wake of rapid urbanization. 
By threading together long-term changes in urban forms, the ritual moments of public hearings, and lived experiences, I argue that under the ideology in which numeric growth equals development and development is inherently good, the structural issue was de-humanized and, to borrow Tania Li's (2007) term, "rendered technical." Infrastructural projects are regarded as technological solutions to a wide range of social and political issues in the process of urbanization; yet their material results are often instead to make these issues invisible.

\section{Evolving Urban Forms, Changed Traffic Patterns}

Guangzhou has a history of settlement of more than a thousand years. But the imagery of old Canton was mostly from the early twentieth century when the city was reshaped by large-scale infrastructural projects. ${ }^{7}$ During the 1920 s and 1930 s, political leaders educated in the United States and Europe considered the old city form - city walls, narrow streets, and overcrowded houses -a serious impediment to their pursuit of modernization. Vehicleoriented streets, with standardized widths of 60 to 100 feet, were built on the remains of city walls and residential houses; the electric grid extended along the newly paved thoroughfares (Zhang 2015a, 2015b). The first bridge across the Pearl River was built, extending urban development beyond the old city wall. This massive construction was halted by the Sino-Japanese war, the Civil War, and the ensuing political turbulence between the mid-1930s and 1940s.

Since the Chinese Communist Party came into power in 1949 up until the early 1990s, urban development took a different mode. The state-orchestrated socialist revolution had implemented central planning for the national economy. Cities were required to transform from spaces of consumption to spaces of production. City centers lost their commercial vibrancy and were transformed into spaces mainly for public performance and political remembrance. The state strictly controlled urban growth through the implementation of household registration, a rationing system for daily necessities, and the urban work unit (danwei) system. Although development remained important in official discourses, emphasis was on the provision of "from cradle to graveyard" care to urban residents, a fundamental socialist ideal. Urban transportation infrastructure was not a priority in the construction list. 
$\mathrm{Lu}(2006)$ coins the term "work unit urbanism" to capture the significant role that the work unit system played in shaping the built environments, social relationships, and life patterns in cities. Work units often had their own workplaces, dining halls, clinics, dormitories, day-care centers, and schools within the vicinity. Many residents did not have to travel far for work. Bicycles were the major vehicles for inner city transportation (Gerth 2010; Notar 2015). Shopping or lingering in shopping areas was not a good part of leisure life (Davis et al. 1995; Yu 2014). Under work unit urbanism, workplaces became the node of socialization and everyday life. These "generalized urban patterns," as Gaubatz $(1995,32)$ names them, created "distinctly undifferentiated social and functional landscapes."

There were both regional and temporal differences in this work unit urbanism. During the period between the 1950s and 1970s, under a planned economy where profits were not the primary goal, neither the government that allocated resources nor the work units had the means to turn the socialist ideal into concrete buildings. A lifestyle centered on one's work unit was most salient in Beijing and cities with heavy industries such as Shenyang and Chongqing. In Guangzhou, only a few big state-owned factories and important government branches had the resources to build a relatively comprehensive set of facilities. In the old city areas, lineage halls and big merchant houses were requisitioned by the state and converted into factories and schools. Old city neighborhoods continued to accommodate the majority of urban residents (Zhang 2015a).

Intriguingly, it is in the early Reform period rather than the Maoist years that work unit urbanism became more dominant in Guangzhou. Post-Mao China has been marked by the removal of political struggle from the state agenda and continuous reforms (Cheek 2006). Early reform efforts took place mostly in the rural areas, and central planning remained a powerful influence in cities in the first two decades. Nonetheless, the re-focus on production and commercial revitalization provided many work units with resources to build dormitories and other facilities that enabled the generalized urban patterns.

In the 1990s the reform emphasis shifted to the urban areas. Reform policies emphasized market mechanisms; the rationing system was gradually abolished (Naughton 2007). The work unit system collapsed with the large-scale bankruptcies of state-owned enterprises. Configurations of a different kind of urban development gradually took hold in the mid-1990s and became the dominant pattern of development in the new millennium. This new form of urban development has distinctive visual markers. First, cities are getting 
noticeably bigger at a fast speed. Although the household registration system has continued to shape the rural-urban divide (Solinger 1999; Whyte 2010), tens of millions of people have moved from the countryside to the cities in the past three decades. In Guangzhou, urban districts grew from 1,444 square kilometers in 1994 to 3,843 in 2014, and the number of residents exceeded 13 million by the end of $2014 .{ }^{8}$

Second, planning and building practices have a specific aesthetic tendency that favors large-scale and spectacular projects. Between 2011 and 2015 I have conducted a number of interviews with young professional planners who are based in Guangzhou, Shenzhen, and Beijing and have been involved, to various degrees, in designing urban development plans for Guangzhou. ${ }^{9}$ They told me that political leaders preferred infrastructural projects that looked stunning. Two planners from Beijing who had drawn up some of Guangzhou's long-term master development plans elaborated on this with the example of the Yangpu Bridge over the Huangpu River in Shanghai, an engineering pride of both the city and the country. At the time of planning there existed an alternative plan to build an underwater tunnel, which would have cost significantly less and relocated fewer residents. However, what one planner said explained it all: "What can you see from the sky if it was a tunnel? A bridge is simply visually stunning! That is why the then prime minister chose it." Projects like this provide impressive images for "the view from the above," 10 and can be easily translated into statistical numbers. They are often presented as milestones of political achievement (zhengji) to political superiors and to the public.

In Guangzhou, this logic of planning and building is best exemplified by the landscape in the Tianhe district. The Tianhe district is located to the east of the old city on the northern bank of the Pearl River. It used to be mostly farmland and villages with an old military airport until the late 1980s. ${ }^{11}$ The municipal government has been actively pushing for infrastructure-led development through planning, encouraging construction, and inviting investment. Funding has come from a wide range of sources from fiscal arrangements to private enterprises to international organizations. Now this area hosts the "central business district" (CBD), with clusters of skyscrapers for offices and luxury hotels, mid- to high-end shopping malls, and residential complexes, where people from migrant workers to educated professionals found employment (figures 1 \& 2). While some villages have become urban enclaves due to the dual land ownership scheme and other contingencies (Siu 2007), others have been demolished to give room for infrastructural 
development. Unlike many streets in the old city that are narrow and windy, streets in Tianhe follow a standard gridded layout and are often wide with ten to fourteen car lanes. Visible flyover crossroads and inner-city highways and a hidden underground train system form a layered transportation network, epitomizing a planning aesthetic that emphasizes both visual and imagined spectacles (figures $3 \& 4$ ). The momentum in building the Tianhe district has been extended to the opposite river bank where relocated government buildings stand next to the landmark Canton Tower.

[insert figures 1, 2, 3, and 4 around here]

In comparison, the old city has had a different experience. The city's incorporation into the global economy has led to the de-industrialization of old city areas. The majority of state-owned and collective enterprises went bankrupt or struggled to survive in the new market-oriented economy. Located often in old city areas, these enterprises sold land rights in order to deal with their financial problems. These bounded patches of land were good for shopping malls and small-scale residential complexes. However, the existing built environment and residents presented great obstacles for the networked infrastructural adjustment and construction. For example, an elevated expressway, the inner ring road (neihuan lu), was constructed in the late 1990s, meandering through the old city and connecting it to the Tianhe district (figure 5). This project was a result of the World Bank and the local government converging initiatives to provide an innovative solution to traffic congestion in a densely populated city (GZJJG 2004). An overhead expressway avoided some of the issues with demolishing a large number of buildings and relocating tens of thousands of residents. But it also raised other issues such as noise control, air pollution, and damages to ground-level businesses, not to mention other constraints in design and implementation.

[insert figure 5 around here]

Old city reconstruction has always been challenging for real estate developers and the local government. Eviction and demolition practices have been widely publicized and criticized. ${ }^{1212}$ Although compensation has routinely been under-evaluated, it is still a big headache for real estate developers and the local government: they have to prepare for a large amount of cash flow, prolonged negotiation, and possibly protests. A local scholar doing government-sponsored policy study of urban development told me in several 
interviews that the government and developers preferred to develop the peri-urban areas, because it was relatively easy to open up space for infrastructural projects there. In contrast, political and economic costs were higher and the finished project would be less visually impressive with old city reconstruction. This preference is clearly shown by comparing a series of master urban development plans, in which the focus of the infrastructure-led development has shifted from the old city areas to new districts since the new millennium.

Spatial specialization gradually rose as a result of planning practices, the new political economy, and constraints of the built environment. The outermost layer of the city was assigned as industrial zones for factories and garages. The originally peri-urban areas in the south now host large gated communities tailored to the rising middle class's desires for spacious and safe living environments. ${ }^{13}$ Further north, places less touched by the real estate fever provide cheap lodging for the millions of migrant workers serving as the labor force for the city's non-stop infrastructural construction and tertiary industries. The old city and Tianhe district became the working, entertainment, shopping, and tourist areas.

Compared to the more generalized urban pattern during the Maoist era, the spatially and functionally specialized pattern has led to a very different pattern of commuting between home, work, and leisure activities. In the morning, more than a million people move toward the city centers, increasingly more the Tianhe district than the old city, from different parts of the city, and vice versa in the evening (also see Deng and Xie 2000; Jing and Wang 2004; Ma 2004; Zhou and Yan 2006). This moving pattern soon exposed the limits of road and railway networks. Traffic jams have become an inevitable part of commuters' lives, and have been built into the daily routine of ordinary citizens. In 2006 and 2007, half of the taxi drivers I talked to thought that building more roads could alleviate the problem of traffic congestion. At that time, rush-hour traffic was terrible, but non-rushhour traffic was acceptable. In the recent three or four years, however, traffic congestion was no longer limited to rush hours, and traffic jams extended from ground-level streets to elevated expressways. The majority of taxi drivers said that no matter how many more roads the government built, they could not solve congestion, because "there [were] too many cars now." Some drivers developed a reluctance to go to the Tianhe district, where there were a lot of wide boulevards that were constantly jammed. Instead, they preferred to meander along the narrower streets of the old city where "cars [could] actually move." 
Spending a long time on the street, taxi drivers have many insights into the structural limitations of transportation infrastructures. Their criticism extended from the design of specific roundabouts to road-bridge connections, and from the intervals between traffic light switches to bus and subway stop locations. They often reminded me not to look at roads as seamless networks: one can build a really wide street, but the street eventually has to end somewhere, or to be connected to other streets. At the joints where the old city meets the new districts, a ten-lane road is often connected to a four-lane or six-lane road or a three-lane bridge. Similarly, at the exits of elevated expressways, ground roads have a sudden increase in traffic. With so many points with a sudden increase in traffic or a reduction of street width, taxi drivers complained, "How can it not have traffic jam?" When it came to the difficulty of finding a taxi, taxi drivers consistently said that issuing more taxi licenses as proposed in the taxi hearings would not help matters, because "the problem [was] not that there [were] not enough taxis, but [that] all the taxis [were] stuck in traffic. The streets are a giant parking lot!"

\section{Staging the Taxi Hearing}

Facing complaints about the difficulty of finding a taxi, the Guanghzou government proposed to issue extra taxi licenses as a solution, and held a series of public hearings between 2007 and 2013. Chinese administrative laws have adopted public hearings since the 1990s as an important forum for the public to communicate with the government without the formalness of a judicial hearing. Conclusions drawn at the end of the public hearings are not legally binding. ${ }^{14}$ The use of public hearings has increased but they remain uncommon in administrative decision-making processes. I have talked to middle-class residents and taxi drivers about different public hearings the Guangzhou government held on issues such as taxi numbers and price increases on water and electricity in the past decade. These conversations indicate that ordinary citizens considered public hearings mere political shows that took place after all decisions had already been made. The significance of the public hearings, however, lies somewhere else. I suggest that the hearings are an important space to facilitate and reinforce the specific way in which infrastructural issues are problematized and articulated. I will elaborate on this with my own participation in the first taxi hearing held in Guangzhou. 
After I signed up to sit in on the hearing and was unexpectedly chosen to be an attendee, I sat with twenty-nine other representatives and GTC officials in a big circle with assigned seating in the GTC conference room on the morning of July 27, 2007. Among the thirty participants were five taxi drivers, five individuals representing the five major taxi companies, and a representative from the Taxi Industry Association. There were also government officials, two experts on transportation (one is a university professor), a university professor, teachers, company employees, and a student (me). Five of the representatives indicated that they had cars. Given their familiarity with the costs and time of public transportation, more than half of the representatives appeared to be frequent users of buses and the subway. In the brief chats before the hearing and their speeches during the hearing, most representatives made it clear that their employers had told them to participate in the hearing, and instructed them to support the government's proposal. Some showed no interest in participating in the hearing. I chatted a bit with the young fellow sitting next to me before the hearing. He told me that his supervisor had sent him, the lowest-ranked employee in a logistics company, because no one else wanted to come. It took him two hours to travel from his home - located in the far north side of the city - to the hearing venue. He had no idea why his company wanted to be involved in the hearing. He personally had no opinion about the government's proposal because taxis were too expensive a transportation means to be relevant to his daily life. When I told him that I registered voluntarily for the event (for auditing), he gasped and said, "You could do that?"

The hearing lasted from nine in the morning to twelve noon. It started with government officials' opening speeches. Then each representative had three minutes to give her/his opinion, but the officials and some representatives spoke much longer. The discussion session was then reduced from the planned thirty minutes to fifteen, which was fine because the majority of the representatives had no intention of speaking again.

The opening speeches were reiterations of what had already been stated in public announcements in the media and in the official document distributed to each representative. Government officials ascribed the difficulty of finding an available taxi to a rising demand for public transportation among urban residents, and proposed that increasing the supply of taxis should match the city's economic development. In response, roughly half of the representatives did no more than restate the official narrative. For most of the rest, their speeches replicated the main writing blocks from the official narrative. ${ }^{15}$ Except Ms. Jia 
(lawyer) and Mr. Chen (taxi driver), all representatives endorsed the government's proposal. ${ }^{16}$

That said, several representatives also showed reservations towards the government's proposal and raised a number of concerns. For the representatives from the taxi industry, the main concern was the possibility of heightened competition resulting in a reduction of income. Four out of five taxi drivers and two of the taxi company representatives were explicit about this potential negative impact. But they did it in a way that they carefully inserted only a few sentences between the formulaic echoes of the official speeches. One taxi company representative opened his speech by saying that the company agreed with the government's proposal. But at the end of his speech, he suggested that the government release more data on the scale and speed of urban growth in tandem with transportation development and that the decision to increase taxicabs be made in five years.

Another major issue of contention was traffic. Lawyer Jia, taxi driver Mr. Chen, Professor Jin the transportation expert, a few other representatives, and I all commented on it. Lawyer Jia and taxi driver Mr. Chen both openly disagreed with the government's proposal to issue 700 new taxi licenses. Lawyer Jia, who was a car owner, argued that, based on her observations, there was no difficulty finding taxis outside rush hour. Mr. Chen pointed out that increasing the number of taxis would only deteriorate traffic, particularly in the Tianhe district. Professor Jin countered the taxi driver's and Lawyer Jia's views. But his argument fell short of a direct support of the government's proposal; rather, it was a compromise between the need to increase taxi supply and to monitor city traffic. He estimated that a taxi would run on average 300 kilometers per day, ten times the average of a private car. Therefore, the proposed increase of taxicabs would lead to more traffic jams. However, according to government's data, 500 new cars were licensed every day in the city. Against this rapid growth of private cars, a one-time increase of 700 taxicabs would not have too much a negative impact on traffic. Meanwhile, if nothing was done to reduce the difficulty in getting a cab, this difficulty would push people to purchase their own cars, which would only worsen traffic. Professor Jin reassured the taxi drivers that the increase would not make an impact on taxi drivers' income, although he did not explain why not.

Another college professor, Professor Feng, devoted most of her time to criticizing the "black cars," the unofficial taxicabs which I discuss in more detail shortly. Professor 
Feng argued that the unofficial cabs ate up the market share, and the increase of 700 taxis would not have a negative impact on the income of taxi drivers if the government could eliminate all black cars.

I agreed with the proposed increase, which was what my informants and interviewees had urged me to do. My reservation was whether the 700 new taxis could fix the problem at issue in a city with over ten million residents. I suggested that the government consider alternative ways to improve the efficiency of street use in the long run, such as designated lanes for buses and taxis. My reservation and suggestion caused some confusion, leading the radio host of a transportation channel to approach me for an interview after the hearing, thinking that I was against the proposal.

This hearing was well covered by various kinds of media. On the Internet were live reports summarizing each representative's speech in one or two sentences. Radio stations hosted interviews with the representatives immediately after the hearing. Evening TV news broadcasts reported the result and some questions raised during the hearing. Local newspapers of the next day recapitulated the hearing, some with details about the reservations and disagreement. Many residents talked about it over dinner with colleagues and families. Although the majority of them considered the government hypocritical in staging the public hearing, they more or less agreed with the government's rationale and initiative.

The details presented here about the hearing may be interpreted in a way to show the complexity of resistance in the liminal space provided by the highly formulaic political performance. But my analysis takes a different focus: what was and was not talked about during the hearing as well as in the pre- and post-hearing discussions in newspapers, online forums, and private conversations. First, traffic congestion was stated as a factual cause for the shortage of taxis, as opposed to being a problem itself worthy of attention. In other words, although traffic was a serious topic that concerned everyone from the municipal government to urban residents, traffic itself did not bring any critical reflections on the ways infrastructural projects and economic development had reshaped urban forms and everyday life. Second, the taxi problem was framed as a matter of numbers: the number of taxis, of private cars, of the size of the city, of residents, and of economic development. These numbers were discussed with seemingly neutral terms such as "income level," "shortage of supply," and "sufficient." A market discourse threaded these numbers together: 
if the taxi problem is due to a heightened demand resulting from economic development, the increase of taxi supply will solve the problem; the demand for taxis will guarantee fair return to the taxi drivers.

Underneath the market discourse, there was another layer of assumptions: growth is simultaneously the means and the end for urban development; growth is primarily a technological, quantifiable issue, and therefore can be addressed through rational calculation and technological intervention. One of the major technological interventions is infrastructure - in this specific case, infrastructure was to build more roads and provide more taxis. Infrastructure was portrayed as inherently good. What were missing were the human, social, and political aspects in the broader discussion of taxis and traffic. There was little discussion regarding, or even mentioning, how infrastructural projects had created spatial segregation, shaped tensions in the organization of transportation, and configured physical immobility and social downward mobility.

This specific way of problematizing and perceiving traffic and taxi issues is promoted and reproduced through the government's master development plans, yearbooks, regular official speech performances, and public events such as the taxi hearing. The significance of the taxi hearing in terms of policy decision-making is minimal. However, its significance can be seen through the analytical lens of secular rituals, as Moor and Myerhoff (1977; see also Abele 1988) suggest,

it is possible to analyze the ways in which ceremony and ritual are used in the secular affairs of modern life to lend authority and legitimacy to the positions of particular persons, organizations, occasions, moral values, view of the world, and the like. In these matters, ritual and ceremony are employed to structure and present particular interpretations of social reality in a way that endows them with legitimacy. Ritual not only belongs to the more structured side of social behavior, it also can be construed as an attempt to structure the way people think about social life. (4; italics in original)

The taxi hearing was one crucial temporal and spatial juncture at which power and a specific development narrative reproduced each other, and by such joint reproduction, inscribed specific ways of ordering, describing, and rationalizing the changes and conflicts in urban life. Unlike official speeches that ordinary people may dismiss as being empty and formulaic, the taxi hearing drew attention from a broad spectrum of audience, who, despite 
their apathy to the hearing per se, were interested in the issue of traffic and possible solutions. By participating in the discussion and even questioning the proposed solution without challenging the underlying logic and assumptions about growth and infrastructure, ordinary citizens all contributed to the perpetuation of the official narrative that sustains the existing mode of urbanism. This narrative about urban development was no longer merely a state propaganda. Instead, it became a tool for ordinary citizens to make sense of some aspects of their everyday life and the city. Yet, this narrative also embodied a regime that made invisible forms of social inequality that had been reconfigured in the process of urban development. One illuminating example is the stories of taxi drivers.

\section{Taxi Drivers: Downward Mobility}

Taxi service first emerged in big Chinese cities in the early twentieth century, but was considered bourgeois and mostly abolished during the Maoist era. Guangzhou was one of the few cities, if not the only one, that still had taxis in the 1960s and 1970s. Thanks to the Canton Fair that was held once a year for China to do foreign trade, the State Council granted Guangzhou permission to have a fleet of taxis in 1956, serving exclusively foreign guests and government officials. Until the 1970s, ordinary citizens had no access to taxi service unless they rode with a foreigner. Taxi fare was paid in waihuiquan (foreign exchange coupons), the currency for foreigners.

Taxi service gradually opened to ordinary citizens in the Reform era and taxis no longer stopped only at designated stations. Guangzhou was the first city that allowed passengers to flag down a taxi anytime, anywhere. Taxi meters were mounted, and prices were calculated in Renminbi (RMB, Chinese Yuan). A rapid expansion of taxi service occurred in the 1980s. The number of taxis increased more than tenfold from only 600 or so at the end of the 1970 s to 7,394 by 1990 . By 1995, it had nearly doubled again. Then the expansion began to slow down and hold stable, reaching 16,889 in 2007.17

From the urban residents' point of view, taxis have never been a primary means of transportation. Up until the early 1990s the majority of residents used taxi service for special occasions such as Chinese New Year. Taxis were also used for weddings when private car ownership was extremely low. A comparison between taxi fares and the annual 
disposable income of the urban residents allows us to gauge, to some degree, the accessibility of taxi service among the local residents over times (Table 1).

Table 1: Taxi Fares and the Monthly Disposable Income of the Urban Residents in Guangzhou in Selected Years (Money in RMB; Distance in Kilometer)

\begin{tabular}{|l|l|l|}
\hline Year & $\begin{array}{l}\text { Monthly Disposable Income of Urban } \\
\text { Residents }\end{array}$ & Taxi Fares \\
\hline 1980 & $¥ 50.5$ & $\begin{array}{l}¥ 1.35 / 3 \mathrm{kms}+¥ 0.45 / \mathrm{km} ; \\
\text { or }\end{array}$ \\
\hline 1997 & $¥ 807.4$ & $¥ 1.50 / 3 \mathrm{kms}+¥ 0.35 / \mathrm{km}$ \\
\hline 2008 & $¥ 2109.8$ & $¥ 7 / 2.3 \mathrm{kms}+¥ 2.2-2.6 / \mathrm{km}$ \\
\hline 2013 & $¥ 3504.1$ & $¥ 7 / 2.3 \mathrm{kms}+¥ 2.6 / \mathrm{km}+¥ 1$ \\
\hline
\end{tabular}

Source: Guangzhou Statistical Yearbooks, based on years when there was a taxi fare adjustment. Exchange Rate: 1RMB equals roughly to 1.5 USD (1980), 8.3 USD (1997), 6.8USD (2008), and 6.1 USD (2013).

In the late 1980 s and early 1990s, driving a taxi was a respectable job. Many taxi drivers used own their taxis. They leased their car and paid it off in three to four years. In essence, they were small business owners, and taxi companies only charged them a small management fee. A taxi driver's income might surpass that of a civil servant or a university professor. Senior taxi drivers recalled state-owned or state-affiliated taxi companies paying for driving lessons that were not offered to the public. Mr. Wang is a good example. An acquaintance of both Mr. Wang and me introduced us to each other and I conducted interviews with him in 2007 after the taxi hearing and again in 2012. In his early fifties in 
2007, Mr. Wang had been a taxi driver since 1991. "Business was good then," he said. "There were constantly passengers waiting in every corner of the city. Private cars were a rarity. Roads may be wider now, but there are also a lot more cars. Before, passengers looked for taxis; now, taxis look for passengers."

In the past two decades, operating a taxi has lost a lot of its appeal (see also Notar 2012; Yu 2006). The increasing purchasing power of the middle class and the construction of large-scale infrastructure have not benefited taxi drivers. There is an apparent downward mobility in social status associated with it, and the feeling that driving a taxi is a lower-class job is now very strong. This downward mobility reflects a shift in perceptions of manual labor, occupation, and social prestige (Hsu 2007). Unlike in the socialist period when being an industrial worker was considered a good social status, in the late Reform era jobs requiring more physical labor and less education are undesirable. Driving a taxi is now seen as requiring relatively low skills and little education but more physical fitness, and has become an option for those, mostly men, ${ }^{18}$ who used to be factory workers, newcomers to the city, and people like Mr. Wang who saw no other options but continued to drive a cab.

Municipal government regulations also changed. Unlike in the 1990s when drivers could become cab owners, new regulations stipulated that only taxi companies could own taxi licenses. The municipal government alleged that the goal of such regulations was to provide safe and reliable taxi service by making taxi companies responsible for quality control. In the same spirit, government regulations also stipulated that taxicabs should be written off after three to five years.

Mr. Wang and his work partner signed a three-year taxi lease with a state-owned taxi company in 2007. They paid over 10,000 RMB (roughly USD 1316) each month for rental and management fees to the company, and shouldered the costs of gas and regular maintenance. Although car prices have dropped consistently over the past decades, taxi rents have not been adjusted substantially. Taxi companies justified the high rental charge by claiming that the requirement to write off taxis regularly has led to high maintenance costs. Many other drivers echoed Mr. Wang's resentment: "In the past, you could say that a car cost a lot, and so they had to charge us a lot. But now each car costs the company less than 100,000 RMB. Yet, we are paying 120,000 RMB for rent each year!” Both casual and formal interviews I conducted with taxi drivers showed that their net income had remained roughly between RMB 4,000 and 5,000 each month since the 1990s. A young taxi driver 
revealed to me in 2007, "Before, being a taxi driver was desirable, because one could make a lot of money. RMB 5,000 in the early 1990s, can you image that? Now, 5,000 not much! You can make a living driving a taxi. You won't starve, but that's it." A strong feeling of being exploited was common among taxi drivers; they could see their hard work turn mostly into profits in the pockets of taxi companies.

If increasing spatial mobility is a blessing for the rising middle class, it seems to be a curse for taxi drivers (see also Notar 2012). Like many drivers, Mr. Wang and his workmate divided each day into two nine-to-ten hour shifts and worked seven days a week. Each cab ran roughly 300 to 380 miles per day (in contrast to Professor Jin's estimation of 186 miles). In the name of safety, state-owned taxi companies require that drivers park their taxis between two and six o'clock in the morning. ${ }^{19}$ Drivers like Mr. Wang complained that they paid higher rent and management fees but worked fewer hours than those contracted with non-state-owned companies, who could work shifts of up to twelve hours. Taxi drivers tended not to take days off; they felt that because rent had to be paid regardless, they might as well maximize their income by driving as many hours as possible. Even when they fell sick, they were not allowed to find a substitute driver to take over a shift.

Taxi drivers did not see the introduction and expansion of the subway system as a real threat to their livelihood. Mr. Wang said, "Every time a new subway line opens, people say taxi drivers' business will be affected. But the truth is it doesn't. Our business may go down a bit for a week, but then everything comes back to normal." They seldom talked about competition from other taxi drivers, but unanimously complained about the flood of "black cars" into the transportation market. The so-called "black cars" are like the "gypsy cars" in New York City: they are formally registered but not licensed to run as taxicabs. They have no meters, and fares are negotiated and agreed upon. They typically look for business outside train stations, large gated communities, and transportation hubs. Their drivers approach anyone appearing to be looking for a taxi. Chen Yang told me when we were stuck in a traffic jam in 2014, "Sometimes I just want to give up this job, get a black car, and run my own business." A young man from a poor town in an adjacent province, Yang had been a taxi driver for seven years in Guangzhou. Chen Yang said, "With a black car you can easily make RMB 4,000 or 5,000 each month but won't have to drive over ten hours each day." “But how are you going to get the car in the first place?" I asked. Chen Yang answered, "That's not difficult-where do you suppose all those written-off taxis have gone?" 
According to taxi drivers, the local government did nothing to keep black cars out of the market. They also pointed out that the number of black cars had increased substantially recently, and some even estimated that one third of the cars providing taxi service were black cars. The black car phenomenon has been exacerbated with the rise of ride-hailing applications such as Uber and Didi chuxing (Didi is the Chinese version of Uber) since the early 2010s. ${ }^{20}$ These apps allow passengers to use their smart phones to conveniently find drivers who may drive taxis or use their private cars. With Didi, consumers can offer tips to attract drivers. The threat posed by this informal taxi service reached a climax in 2014 and 2015 when online payment platforms sought aggressively to expand their market share. Operated by Chinese Internet giants such as Alibaba and Tencent, these platforms worked with transportation network companies to provide generous subsidies to attract both consumers and drivers. When I sat in his taxi in October 2015, Mr. Yu told me that a friend of his invested all his money to buy a car and to take orders from Uber and Didi in 2014; in one year's time, he had gotten all his investment back. Mr. Yu said, "It's so easy to make money if one doesn't have to pay the taxi company. I wish I had his courage last year."

Taxi drivers admitted that the government had had great achievements in connecting different parts of the city with roads, bridges, and public transportation in the past two decades. However, taxi drivers increasingly felt trapped in the ever-expanding road network. Chen Yang told me that some companies had licensed taxis but could not recruit enough drivers. He sighed, “Driving a taxi is a really tough job. People simply don't want to do it. The government can continue to issue more taxi licenses, but no one wants them." The reason is not simply that the private car consumption has pushed them to the margin. Factors are multiple: the abovementioned vision of urban development, the faith in infrastructure, street layout and urban forms, government regulations, corporate interests, and the middle-class's desire for individual mobility, all of which have led to taxi drivers' reduction in mobility.

\section{Conclusion}

The knowledge-power apparatus that sees cities as "growth machines" (Molotch 1976; Smith 2002) has shaped powerful development projects across the globe in the past decades. These projects, in one way or another, have placed infrastructures in their action plans. The failure to implement infrastructural construction projects is often seen as a sign 
of political incapacity and socioeconomic instability. An array of actors have led and molded this process. On the transnational level, governmental and non-governmental organizations, charitable agencies, and global capital provide policy guidance, initiatives, financial resources, and discourses for urban development in an unprecedented manner. In China, this infrastructure-centered, growth-oriented model of urban development is also a national project, allowing the ruling party and local governments to cope with a changing political ideology and economy. Equally important actors also include those self-identified "ordinary" citizens such as the planners who juggle their visions with a political aesthetic, middle-class individuals who actively pursue a mobile lifestyle and upward social mobility, and the many formal and informal taxi drivers who seek to make a living in the economy of mobility.

Yet, infrastructures for transportation and spatial mobility are more than passive objects of human design and engineering. They are massive and interwoven; they are challenging to build and more difficult to modify, upgrade, or redo. They are directive in configuring options and possibilities for everyday life and future changes. They contribute to the circulation of people, objects, and ideas, but they also bring ruptures. The difficulty of finding a taxi as analyzed here epitomizes the dead ends, bottlenecks, friction, jolts, and jerks in an infrastructural process shaped by urban development projects in Guangzhou.

The Guangzhou stories presented here have local specificities, but are by no means unique. For example, in the southwestern city of Kunming, the urban landscape has been reconfigured with the rise of middle-class gated communities (Zhang 2010). Yet the upward mobility of the emerging middle class stands in strong contrast to the downward mobility of taxi drivers who see themselves trapped in the iron cages (Notar 2012). Guangzhou's experience is an intense version of the general trends in urban development in China and beyond (Hansen 2006; Harms 2011; Mathew 2005). These urban development projects are framed and justified by a grandiose narrative about numbers, achievement, progress, and modernity, which is visualized and symbolized by spectacular infrastructural projects, such as wide boulevards in an extensive road network. Yet, infrastructural facilities are also lived-in spaces where people like taxi drivers make a living. For those whose livelihood depends on the infrastructure, their stories often carry a less triumphant tone.

This article does not mean to label this specific model and logic of urban development either "good" or "bad." Rather, it unpacks how an infrastructural process, 
shaped by this specific mode and logic of urban development, has contoured a physical space, endowed daily lives with forms and meanings, and structured the emergence of particular class relationships. In doing so, this article seeks to denaturalize the generally accepted way of thinking about infrastructure and urban development, expose (infra)structural violence, and gain a greater understanding of the interplay between spatial politics and the reinforcement of political legitimacy, which is well illustrated in the taxi hearings.

In a series of taxi hearings, ordinary people are not simply coerced into this mode of urban development. It is true that, on the one hand, the hearing manifested the power of the state in soliciting compliance. The taxi industry and drivers were uncertain about the government's proposal, but they said what the government wanted to hear, because they knew they would be punished otherwise. The representative from a major taxi company objected to a similar proposal in a hearing in 2008, not to challenge the predatory logic of infrastructure and development, but rather to speak out about their taxi drivers' concerns. As a result, this company was excluded from bidding for the newly released 1,100 taxi licenses. No taxi companies have raised objections in subsequent hearings.

On the other hand, the hearing also illuminates how different people - officials, scholars, drivers, and non-drivers - have played a role in perpetuating this model of urban development by subscribing to the grand narrative about it. They celebrated large-scale infrastructural building achievements, which they think make the city look "modern." Although these infrastructural projects are usually products of joint efforts by government agencies, global capital, international design firms, and research institutes, ordinary residents gave the credit to the municipal government. They complained about specific planning and building decisions, and blamed the government or specific officials for those decisions. But they rarely questioned the official model of infrastructural building and urban development. Ordinary residents like the taxi drivers and members of the middle class see this model of urban development as logical, and their dissatisfaction, frustration, and upward or downward social mobility as natural and inevitable in the process of such development. This infrastructural violence is neutralized by the official discourse on largescale infrastructural building as progress and economic development. Thus, despite the wide range of human experiences in the processes of urban development, the specular infrastructural projects and the official narratives about progress, modernity, and 
urbanization continue to provide the state and the ruling party with political legitimacy in the absence of ordinary citizens' political participation.

Acknowledgements: Fieldwork for this research between 2006 and 2007 was supported by the International Dissertation Research Fellowship from the Yale Center for International and Area Studies and East Asian Studies Dissertation Research Grants from the Council of East Asian Studies at Yale University. Follow-up research was funded by Council on East Asian Studies Summer Travel and Research Grants at Yale University in 2008, and the Seed Funding for Basic Research and the Hang Seng Bank Golden Jubilee Education Fund from the University of Hong Kong from 2014 to 2015. I am grateful to the insightful comments of two anonymous reviewers, Dr. Gonçalo Santos, and Dr. Minhua Ling.

\section{References}

Abeles, Marc. 1988. "Modern Political Ritual: Ethnography of an Inauguration and a Pilgrimage by President Mitterrand." Current Anthropology 29(3): 391-404.

Abramson, Daniel Benjamin. 2007. "The Aesthetics of City-scale Preservation Policy in Beijing." Planning Perspectives 22(2): 129-166.

Anagnost, Ann. 2008. "From 'Class' to 'Social Strata': Grasping the Social Totality in Reformera China.” Third World Quarterly 29(3): 497-519.

Anand, Nikhil. 2011. "Pressure: The PoliTechnics of Water Supply in Mumbai." Cultural Anthropology 26(4): 542-564.

_. 2012. "Municipal Disconnect: On Abject Water and its Urban Infrastructures." Ethnography 13(4): 487-509.

Blussé, Leonard. 2008. Visible Cities: Canton, Nagasaki, and Batavia and the Coming of the Americans. Cambridge, Massachusetts: Harvard University Press.

Bunnell, Tim. 1999. "Views From Above and Below: The Petronas Twin Towers and/in Contesting Visions of Development in Contemporary Malaysia." Singapore Journal of Tropical Geography 20(1): 1-23.

Campanella, Thomas J. 2008. The Concrete Dragon: China's Urban Revolution and What it Means for the World. New York: Princeton Architectural Press.

Chao, Emily. 2003. “Dangerous Work: Women in Traffic.” Modern China 29(1): 71-107.

Cheek, Timothy. 2006. Living with Reform: China since 1989. Nova Scotia; London; New York: Zed Books.

Chu, Julie Y. 2014. "When Infrastructures Attack: The Workings of Disrepair in China." American Ethnologist 41(2):351-367.

Coleman, Leo. 2014."Infrastructure and Interpretation: Meters, Dams, and State Imagination 
in Scotland and India." American Ethnologist 41(3): 457-472.

Davis, Deborah, Richard Kraus, Barry Naughton, and Elizabeth Perry, eds. 1995. Urban Spaces in Contemporary China: The Potential for Autonomy and Community in Post-Mao China. Cambridge [England]; New York: Woodrow Wilson Center Press; Cambridge University Press.

Deng, Maoying, and Li Xie. 2000. “Guangzhoushi Jumin Chuxing Tezheng Fenxi ji Jiaotong Fazhan de Duice" (The Characteristics of the Trips of the Local Residents and the Transport Policy in Guangzhou). Chengshi Guihua 24(11): 45-49.

Dong, Madeleine Y.. 2003. Republican Beijing: The City and its Histories. Berkeley: University of California Press.

Ergenc, Ceren. 2012. "Public Hearings as a Venue for Representation and Participation in Reform Era China.” PhD Diss., Boston University.

Esherick, Joseph, ed. 2000. Remaking the Chinese City: Modernity and National Identity, 1900-1950. Honolulu: University of Hawai'i Press.

Ferguson, James. 2012. “Structures of responsibility.” Ethnography 13(4): 558-562.

Furlong, Kathryn. 2014. “STS beyond the 'Modern Infrastructure Ideal': Extending Theory by Engaging with Infrastructure Challenges in the South." Technology in Society 38(0): 139-147.

Gaubatz, Piper R.. 1995. "Urban Transformation in Post-Mao China: Impacts of the Reform era on China's Urban Form." In Urban Spaces in Contemporary China: The Potential for Autonomy and Community in Post-Mao China, edited by Deborah Davis, Richard Kraus, Barry Naughton, and Elizabeth Perry, 28-60. Cambridge [England]; New York: Woodrow Wilson Center Press; Cambridge University Press.

Gerth, Karl. 2010. As China Goes, So Goes the World: How Chinese Consumers Are Transforming Everything. New York: Hill and Wang.

Graham, Stephen, and Simon Marvin. 2001. Splintering Urbanism: Networked Infrastructures, Technological Mobilities and the Urban Condition. London; New York: Routledge.

Graham, Stephen, and Colin McFarlane, eds. 2014. Infrastructural Lives: Urban Infrastructure in Context. Abingdon, Oxon; New York, NY: Routledge.

GCGF (Guangzhou Chengshi Guihua Fazhan Huigu Bianzuan Weiyuanhui; Editing Committee of Guangzhou Urban Planning Development Review), ed. 2005. Guangzhou Chengshi Guihua Fazhan Huigu (1949-2005) (Shangjuan) (Guangzhou Urban Planning Development Review: 1949-2005 (Volume I)). Guangzhou: Guangdong Keji Chubanshe. 
GZJJG (Guangzhoushi Zhongxinqu Jiaotong Jianshe Gongsi; Transporation Construction For the Central District in Guangzhou City, Co.), ed. 2004. Zhongguo Daxing Shizheng Gongcheng Sheji yu Shigong: Guangzhou Neihuanlu (Designs and Implementation of the Large Infrastructure Projects in China: Guangzhou's Neihuan Lu). Shanghai: Shanghai Jiaotong Daxue Chubanshe.

GSY (Guangzhou Tongji Nianjian; Guangzhou Statistical Yearbook), from 1979 to 2014.

Hansen, Thomas Blom. 2006. "Sounds of Freedom: Music, Taxis, and Racial Imagination in Urban South Africa." Public Culture 18(1):185-208.

Harms, Erik. 2011. "Material Symbolism on Saigon's Edge: The Political-Economic and Symbolic Transformation of Ho Chí Minh City's Periurban Zones.” Pacific Affairs 84(3): 455-473,420.

Hsing, You-tien. 2010. The Great Urban Transformation: Politics of Land and Property in China. Oxford: Oxford University Press.

Hsu, Carolyn L. 2007. Creating Market Socialism: How Ordinary People Are Shaping Class and Status in China. Durham: Duke University Press.

Humphrey, Caroline. 2005. "Ideology in Infrastructure: Architecture and Soviet Imagination." Journal of the Royal Anthropological Institute 11(1): 39-58.

Jing, Guosheng, and Bo Wang. 2004. “Guangzhoushi Jumin Chuxing Tezheng Bianhua Qushi Fenxi (Characteristics of the Trips of the Local Residents in Guangzhou)." Huazhong Keji Daxue Xuebao (Chengshi Kexue Ban) (June): 88-92.

Joniak-Lüthi, Agnieszka. 2016. "Roads in China's Borderlands: Interfaces of Spatial Representations, Perceptions, Practices, and Knowledges." Modern Asian Studies 50(01):118-140.

Kaika, Maria, and Erik Swyngedouw. 2000. "Fetishizing the Modern City: The Phantasmagoria of Urban Technological Networks." International Journal of Urban and Regional Research 24(1): 120-138.

Li, Tania. 2007. The Will to Improve: Governmentality, Development, and the Practice of Politics. Durham: Duke University Press.

Lu, Duanfang. 2006. Remaking Chinese Urban Form: Modernity, Scarcity, and Space, 19492005. London; New York: Routledge.

Ma, Xiaoyi. 2004. "Guangzhoushi Jumin Chuxing Fangshi Jiegou Bianhua de Qishi" (Enlightenment on the Variations in the Structure of Guangzhou Inhabitant Mode Share). Chengshi Jiaotong (2): 29-32.

Mains, Daniel. 2012. "Blackouts and Progress: Privatization, Infrastructure, and a Developmentalist State in Jimma, Ethiopia." Cultural Anthropology 27(1): 3-27. 
Mathew, Biju. 2005. Taxi!: Cabs and Capitalism in New York City. New York: New Press.

Meyer, Michael. 2008. The Last Days of Old Beijing: Life in the Vanishing Backstreets of a City Transformed. New York: Walker \& Company.

Molotch, Harvey. 1976. "The City as a Growth Machine: Toward a Political Economy of Place." American Journal of Sociology 82(2): 309-332.

Moore, Sally Falk, and Barbara G. Myerhoff. 1977. "Introduction: Secular Ritual: Forms and Meanings.” In Secular Ritual, edited by Sally F. Moore and Barbara G. Myerhoff, 3-24. Assen: Van Gorcum.

Mosher, Steven. 1985. Journey to the Forbidden China. New York; London: Free Press; Collier Macmillan.

Naughton, Barry. 2007. The Chinese Economy: Transitions and Growth. Cambridge, Mass.: MIT Press.

Notar, Beth E. 2012. "'Coming Out' to 'Hit the Road': Temporal, Spatial and Affective Mobilities of Taxi Drivers and Day Trippers in Kunming, China." City \& Society 24(3): 281-301.

_. 2015. "From Flying Pigeons to Fords: China's New Car Culture." In East Asia in the World: An Introduction, edited by Anne Prescott, 122-139. New York, NY: Routledge.

Ong, Aihwa. 2011. "Hyperbuilding: Spectacle, Speculation, and the Hyperspace of Sovereignty." In Worlding Cities: Asian Experiments and the Art of Being Global, edited by Ananya Roy and Aihwa Ong, 205-226. Chichester, West Sussex; Malden, MA: WileyBlackwell.

Ren, Xuefei. 2011. Building Globalization: Transnational Architecture Production in Urban China. Chicago: University of Chicago Press.

_. 2014. "The Political Economy of Urban Ruins: Redeveloping Shanghai." International Journal of Urban and Regional Research 38(3): 1081-91.

Roy, Ananya, and Aihwa Ong, eds. 2011. Worlding Cities: Asian Experiments and the Art of Being Global. Chichester, West Sussex; Malden, MA: Wiley-Blackwell.

Scott, James C. 1998. Seeing like a State: How Certain Schemes to Improve the Human Condition Have Failed. New Haven; London: Yale University Press.

Siu, Helen F. 2007. “Grounding Displacement: Uncivil Urban Spaces in Postreform South China." American Ethnologist 34(2): 329-350.

Smith, Neil. 2002. "New Globalism, New Urbanism: Gentrification as Global Urban Strategy." Antipode 34(3): 427-450. 
Solinger, Dorothy J. 1999. Contesting Citizenship in Urban China: Peasant Migrants, the State, and the Logic of the Market. Berkeley: University of California Press.

Tomba, Luigi. 2004. "Creating an Urban Middle Class: Social Engineering in Beijing." The China Journal (51): 1-26.

Tsin, Michael T..1999. Nation, Governance, and Modernity in China: Canton, 1900-1927. Stanford, California: Stanford University Press.

Van Dyke, Paul. 2005. The Canton Trade: Life and Enterprise on the China Coast, 1700-1845. Hong Kong; London: Hong Kong University Press.

Whyte, Martin King, ed. 2010. One Country, Two Societies: Rural-urban Inequality in Contemporary China. Cambridge, Mass.: Harvard University Press.

Yu, Fang (dir.). 2006. Women at the Wheel: Die Taxischwestern von Xian (documentary). 72 mins. Kloos \& Co. Medien GmbH. China/Germany.

Yu, LiAnne. 2014. Consumption in China: How China's New Consumer Ideology Is Shaping the Nation. Cambridge, UK: Polity Press.

Yurchak, Alexei. 2003. "Soviet Hegemony of Form: Everything Was Forever, Until It Was No More." Comparative Studies in Society and History 45(03): 480-510.

Zhang, Jun. 2015a. “The Rise and Fall of Qilou: Metamorphosis of Forms and Meanings of Built Environments in Guangzhou (Canton), China." Traditional Dwellings and Settlements Review 26(2): 25-40.

_. 2015b. "Materializing a New Form of Governance: When Streets Building Intersected with State Building in the Early Twentieth-century Canton, China." Presentation at the workshop "Infrastructures: Provocations towards an Inter-disciplinary Dialogue," National University of Singapore.

_. 2016. "(Extended) Family Car, Filial Consumer-Citizen: Being Properly Middle-class in Post-socialist South China." Modern China. First published online on April 22, 2016 as doi: $10.1177 / 0097700416645138$.

Zhang, Li. 2010. In Search of Paradise: Middle-class Living in a Chinese Metropolis. Ithaca: Cornell University Press.

Zhou, Suhong, and Xiaopei Yan. 2006. "Guangzhou Chengshi Juzhu Jiuye Kongjian ji dui Jumin Chuxing de Yingxiang" (Relationship between Urban Residential Space and Employment Space and Impact on Resident Trip in Guangzhou). Chengshi Guihua 30(5): 13-18, 26. 
Notes

${ }^{1}$ I use the term "middle class" to refer to government bureaucrats, professionals, and small-time entrepreneurs. I have discussed elsewhere the difficulty and politics of defining "middle class" in China (Zhang 2016; also Anagnost 2008; Tomba 2004; Zhang 2010).

2 The United Nations' description of urbanization is a good example. See http://www.un.org/en/development/desa/population/theme/urbanization/ accessed January 6, 2015.

3 The China data in the "urban population" session, accessed March 28, 2016. http://data.worldbank.org/indicator/SP.URB.TOTL.IN.ZS?page=6. The World Bank data come from national governments' statistics. It is well known that the Chinese government's data is problematic, but there is a lack of alternative reliable data.

4 The Chinese government clearly articulated this view after China and the African Union signed a memorandum on infrastructural development in January 2015. The spokeswoman from China's Ministry of Foreign Affairs stated that "in order to get rich, the roads need to be built first" (yao xiang fu, xian xiulu); this was an important experience for China's development in the past thirty years, and it would be essential for Africa's development as well (accessed January 30, 2015. http://www.gov.cn/xinwen/201501/28/content 2811456.htm). Such a view is not unique to China. Scholars have observed a similar discourse of infrastructure as progress in other places in Asia and Africa. See, for example, the special issue "Roads and Anthropology" in the journal Mobilities, 7 (4), 2012. See also Harms (2011) and Mains (2012).

5 The journal Geoforum dedicated a special issue (vol. 39, no.6) to the discussion of splintering urbanism in 2008. The International Journal of Urban and Regional Research has two special issues on infrastructure and urban life (March 2000 and June 2008). See also Graham and McFarlane (2014).

${ }^{6}$ All data mentioned in this paragraph are from GSY, from 1980 to 2015.

${ }^{7}$ Cities in China had gone through substantial conceptual, administrative, and political transformations in the early twentieth century (Esherick 2000; Zhang 2015b). Canton was the first to establish a municipal government (Tsin 1999), followed by many other cities. However, today's popular views, mass media, and many academic works usually consider the urban form that emerged during this period - including Guangzhou, Beijing and other historic cities - as representative of "traditional" Chinese cities (Dong 2003; Zhang 2015a). 
8 The concept "city" as used in "Guangzhou city" in recent official statistics is closer to "metropolitan area" than "city" in the American context. Today's city of Guangzhou includes the urban districts and several county-level cities, and the latter have certain administrative autonomy. The numbers on the city size over the years come from GSY (2015). GSY (2015) records 8.42 million residents with local household registration in 2014 , but the 13 million refers to the actual residents, including those without local household registration (accessed on May 13, 2016. http://www.gzstats.gov.cn/tjgb/qtgb/201504/t20150430_37572.htm).

${ }^{9}$ Upon request, all planners and scholars quoted in this article are anonymous, except for those whose names were already published in newspapers.

10 For more discussion of "the view from the above" in China and Southeast Asian cities, see Abramson (2007), Bunnell (1999) and Ong (2011); for a more general discussion, see Scott (1998).

${ }^{11}$ According to Guangzhou Statistical Yearbooks, Tianhe was glossed together with other agricultural land under the suburban (jiaoqu) category in official statistics until 1984. It became an urban district in 1985. Mosher (1985) has a vivid description of farming in today's Tianhe area when he drove out of the old city of Guangzhou in 1980. Also see GCGF (2005).

12 Scholars have investigated brutal forms of eviction and demolition practices during urban redevelopment in China (Campanella 2008; Chu 2014; Hsing 2010; Ren 2014). However, it shall be noted that, first, existing scholarship may not have paid enough attention to the substandard living conditions in old city neighborhoods, and to the fact that not all original residents were forced to comply with the redevelopment plans (Zhang 2015a; Meyer 2008). Second, existing works tend to focus on demolition for the purpose of profitable real estate development instead of that for infrastructural construction; the latter usually received less public criticism than the former.

${ }^{13}$ For detailed description of the rise of middle-class gated communities, see Zhang (2010).

${ }^{14}$ For more information on the legal regulations, see Ergenc (2012).

15 Yurchak's description of writing blocks in ideological texts in the former Soviet Union is illustrative and applicable in the China's context. These blocks are usually products of collective writing and cross imitation of other official narratives. They substantially reduce the individuality of the text and increase the potential of replicability (Yurchak 2003). 
16 I use pseudonyms for all participants mentioned here except Lawyer Jia and Professor Jin, because the latter were mentioned in the newspaper reports while the rest not.

${ }^{17}$ All numbers mentioned in this paragraph come from GSYs.

18 For descriptions of the role of gender in China's taxi industry, see Chao (2003) and Yu (2006).

${ }^{19}$ Among tens of taxi companies, more than half of the taxi license plates belonged to three state-owned companies, whose taxis are marked by distinctive colors. More than half of the newly issued licenses after the taxi hearings also went to the big three.

20 It is still too early to assess the full impacts of transportation network companies in shaping public transportation. As I revised this article, companies like Uber are confronted with increasing challenges from local governments, taxi drivers, and labor unions across the globe. Meanwhile, in China these companies have reduced subsidies, and Uber left China in 2016. On the other hand, companies such as the electronic giant Apple has invested one billion dollars in Didi in the same year. 